Original Research

\title{
Durability of Alkali-Activated Materials Made with a High-Calcium, Basic Slag
}

Omar Alelweet, Sara Pavia *

Dept. of Civil Engineering, University of Dublin, Trinity College Dublin. Ireland; E-Mails: alelweeo@tcd.ie; pavias@tcd.ie

* Correspondence: Sara Pavia; E-Mail: pavias@tcd.ie

Academic Editor: Jorge de Brito

Special Issue: New Trends on Circular Economy Building and Construction Materials

Recent Progress in Materials

2021, volume 3, issue 4

doi:10.21926/rpm.2104041
Received: June 09, 2021

Accepted: September 26, 2021

Published: October 13, 2021

\begin{abstract}
Alkali activated (AA) materials have been investigated for decades as an alternative to Portland cement (PC) products. Most consist of a silicate waste activated with alkalis, which leads to lower green-house gas emissions and a substantial drop in the use of unrenewable material resources. This paper studies the durability of AA materials made with a ground granulated blast furnace slag (GGBS) from Dublin, activated with sodium hydroxide $(\mathrm{NaOH})$, and sodium silicate $\left(\mathrm{Na}_{2} \mathrm{SiO}_{3}\right)$, both combined and separately, and cured at 20 and $60^{\circ} \mathrm{C}$. The long-term strength and durability were assessed with accelerated weathering tests using thermal-moisture cycling, salt crystallization and freeze-thaw cycling. The 28-day strengths are compared to the 270 -day strengths. The mass loss and macro/microscopic changes were investigated. The slag complies with standard requirements being ultra-fine (SSA=1950 $\mathrm{m}^{2} / \mathrm{kg}$ ), basic (1.56 basicity- $\mathrm{CaO}+\mathrm{MgO} / \mathrm{SiO}_{2}$ ) and highly amorphous. It is adequate for alkali activation, having a $\mathrm{CaO} / \mathrm{SiO}_{2}$ ratio of 1.41 and a $\mathrm{Al}_{2} \mathrm{O}_{3} / \mathrm{SiO}_{2}$ ratio of 0.34 . Melilite is the main constituent of the slag, in an isomorphous solid solution with gehlenite as the end member. The results evidenced that mechanical strength is not compromised over time, but it tends to significantly increase between 28 and 270 days. Despite the exaggerated weathering conditions of the laboratory cycling, the strength loss and micro/macro damage after cycling
\end{abstract}

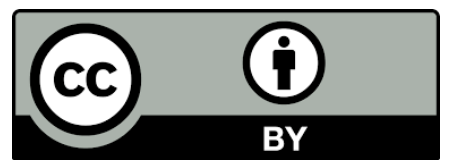

(c) 2021 by the author. This is an open access article distributed under the conditions of the Creative Commons by Attribution License, which permits unrestricted use, distribution, and reproduction in any medium or format, provided the original work is correctly cited. 
is minimum, except for a few of the $\mathrm{Na}_{2} \mathrm{SiO}_{3}$ activated slag specimens. The $\mathrm{Na}_{2} \mathrm{SiO}_{3}+\mathrm{NaOH}$ activated GGBS materials showed the greatest resilience to the effects of frost, thermal/moisture and salts, as they remained intact and showed the greatest strenghts after cycling, and an unaltered microstructure consisting of unreacted GGBS and scattered silica cements alternating with alumino-silicates. In contrast, both the $\mathrm{NaOH}$ and the $\mathrm{Na}_{2} \mathrm{SiO}_{3}$ activated GGBS materials were slightly damaged displaying salt efflorescence and microcracks. Increasing the curing temperature does not increase the durability of the AA slag specimens as it doesn't significantly enhance the late mechanical strength. However, it slightly improves the strengths of the $\mathrm{Na}_{2} \mathrm{SiO}_{3}+\mathrm{NaOH}$ and $\mathrm{NaOH}$ activated mixes but lowers the strengths of the $\mathrm{Na}_{2} \mathrm{SiO}_{3}$ specimens.

\section{Keywords}

Alkali activation; GGBS; durability; strength

\section{Introduction}

The search for alternative binders with a lower environmental impact than Portland cement (PC) is much needed in construction, and consequently, much research on this subject has been produced in the last years. However, PC production continues to raise, despite being repeateadly flagged as one of the main contributors to $\mathrm{CO}_{2}$ emissions worldwide. Global $\mathrm{CO}_{2}$ emissions from 1928 to 2018 have been calculated at 36-40 $\mathrm{Gt} \mathrm{CO}_{2}$ [1].

For decades, slags such as ground granulated blast furnace slag (GGBS) have been used heavily, as PC replacement, to reduce the environmental impact of PC production. As PC replacement, GGBS has been proven to decrease chloride diffusion [2], reduce creep and drying shrinkage [3], increase sulfate resistance [4, 5], enhance strength [6], reduce the heat of hydration and bleeding [7] and increase durability in the aggressive environment of farming silos [8].

Research has shown that it is possible to develop cements based solely on slags activated with alkali compounds such as $\mathrm{NaOH}, \mathrm{Na}_{2} \mathrm{SiO}_{4}$ and $\mathrm{Na}_{2} \mathrm{CO}_{3}$ [9-14]. In the literature these are named either alkali-activated slag (AAS) cements or geopolimers.

Properties of alkali-activated slag materials. Slags differ in chemical composition, and this impacts their hydraulic properties and the physical properties of the resultant materials. $\mathrm{The}^{\mathrm{SiO}}{ }_{2}$, $\mathrm{CaO}, \mathrm{Al}_{2} \mathrm{O}_{3}$ and $\mathrm{MgO}$ contents determine reactivity and the properties of the resultant materials, as they dissolve in alkaline conditions providing the elements necessary for the formation of hydraulic hydrates.

Shi et al. [15] studied the differences in composition of furnace slag from several countries in the world concluding that they have very similar $\mathrm{SiO}_{2}$ and $\mathrm{CaO}$ contents, but the $\mathrm{Al}_{2} \mathrm{O}_{3}, \mathrm{MgO}$ and $\mathrm{TiO}_{2}$ contents can vary. Table 1 compares the chemical composition of the slag investigated with others in the literature. As it can be seen from this table, the slags have similar chemical composition. Alkali activation is an agressive chemical process where the nature of the alkali activator and its concentration largely override the input of the slag properties and composition. According to Fernández-Jiménez et al. [9] the nature of the alkaline activator is the most significant factor in 
Recent Progress in Materials 2021; 3(4), doi:10.21926/rpm.2104041

the development of mechanical strength, overriding the effects of specific surface area of the slag, curing temperature and activator concentration. 
Table 1 Chemical composition of the slag investigated compared with others in the literature.

\begin{tabular}{|c|c|c|c|c|c|c|c|c|c|c|c|}
\hline & $\mathrm{SiO}_{2}$ & $\mathrm{Al}_{2} \mathrm{O}_{3}$ & $\mathrm{CaO}$ & MgO & $\mathrm{Fe}_{2} \mathrm{O}_{3}$ & $\mathrm{Na}_{2} \mathrm{O}$ & $\mathrm{K}_{2} \mathrm{O}$ & $\mathrm{P}_{2} \mathrm{O}_{5}$ & $\mathrm{SO}_{3}$ & $\mathrm{TiO}_{2}$ & MnO \\
\hline Collins and Sanjayan $(2001)[16,17]$ & 35.04 & 13.91 & 39.43 & 6.13 & 0.29 & 0.34 & 0.39 & $<0.1$ & - & 0.42 & 0.43 \\
\hline $\begin{array}{l}\text { Fernández-Jiménez et al. (1999)[9] } \\
\text { Puertas et al. (2002)[18] }\end{array}$ & 35.50 & 12.15 & 41.45 & 8.34 & 1.01 & 0.58 & 0.64 & & 2.47 & - & - \\
\hline Altan and Erdoğan (2012)[19] & 39.90 & 11.13 & 34.56 & 9.37 & 0.26 & 0.35 & 1.18 & - & 0.09 & - & - \\
\hline Bakharev at al. $(1999,2002)[10,20]$ & 35.04 & 13.91 & 39.43 & 6.13 & 0.29 & 0.34 & 0.39 & $<0.1$ & - & 0.42 & 0.43 \\
\hline San Nicolas et al. (2014)[21] & 33.70 & 12.80 & 45.40 & 1.00 & 1.00 & 0.10 & & - & - & 0.50 & - \\
\hline Qureshi and Ghosh (2014)[22] & 32.50 & 18.50 & 33.50 & 8.00 & 0.40 & 0.70 & 0.40 & - & 0.5 & 1.01 & 0.55 \\
\hline Slag in this paper & 32.00 & 12.00 & 42.00 & 8.00 & 0.45 & 0.03 & 0.71 & 0.42 & 2.20 & 0.75 & 0.20 \\
\hline
\end{tabular}


The amorphousness and the basicity of the slags also impact reactivity. The GGBS used is highly amorphous and basic, with a basic index of $\mathrm{CaO}+\mathrm{MgO} / \mathrm{SiO}_{2}=1.56$ [23]. The vitreousness compares well with most in the literature $[15,18]$. However, the basicity is slightly greater than in other slags previously reported (Table 1). The more basic the slag the greater its hydraulic activity in the presence of alkali activators [24]. In general, glassy slags with $\mathrm{CaO} / \mathrm{SiO}_{2}$ ratios between 0.50 and 2.0, and $\mathrm{Al}_{2} \mathrm{O}_{3} / \mathrm{SiO}_{2}$ ratios between 0.1 and 0.6 are considered suitable for alkaliactivation [25]. The ratios in the slag investigated are 1.41 and 0.34 respectively, therefore it is suitable for alkali activation. In addition, the slag complies with the standard chemical requirements for the use of slags in concretes mortars and grouts EN15167-1:2006.

Some of the challenges for alkali-activated slag materials are comprehensively summarised in Shi et al. [15] including: The appearance of alkali carbonate efflorescence due to the leaching of alkalis and their reaction with the $\mathrm{CO}_{2}$ in the air; cracking due to drying shrinkage, and the potential expansion by alkali-aggregate reaction.

Durability of alkali activated slag materials. AA slag materials are reported by former authors as sulphate resistant. They have a better resistance to sulfate attack than PC, which has been often associated to the lower content or absence of tricalcium aluminate $\left(C_{3} A\right)$ in the slag materials [18, 20, 26].

Puertas et al. [18] demonstrated that alkali-activated slag mortars are high sulfate resistant materials, having an outstanding resistance to sulfates and seawater attack, in particular waterglass-activated slag mortars. The authors also state that $\mathrm{NaOH}$ activated slag mortars were slightly sensitive to sulphate and to sea water attack, forming some gypsum and ettringite which slightly decreased mechanical strengths. Bakharev et al. [20] agree on the high resistance to salt attack (magnesium sulfate and sodium sulfate solutions) of AA slag materials, and the higher sensibility of $\mathrm{NaOH}$-activated slag mortars to sulphate attack when compared to the $\mathrm{Na}_{2} \mathrm{SiO}_{3}-$ activated ones. After 12 months of exposure to sulfate solutions, the strength decrease was $17-23 \%$ for AAS concrete vs $25-37 \%$ for PC concrete. The main products of degradation were ettringite and gypsum in the PC and gypsum in AAS materials. Waterglass-activated slag mortars have been reported to undergo a negligible expansion following exposure to $\mathrm{Na}_{2} \mathrm{SO}_{4}$ solution [18]. Similarly, Bakharev et al. [20], also found that the AAS samples did not expand but slightly cracked in sodium sulfate solutions.

Several authors have observed that the interfacial transition zone, a weaker area in PC materials which is susceptible to decay, is highly dense and uniform in alkali-activated slag concretes [21, 27, 28]. San Nicolas et al. [21] illustrated two mechanisms in AA slag materials that develop a compact and homogeneous matrix at advanced ages: the reaction of slag particles through an Ostwald supersaturation-nucleation-depletion cycle, and the precipitation of $\mathrm{Ca}(\mathrm{OH})_{2}$ from the pore solution in microcracks, closing cracks, hence avoiding the ingress of aggressive agents to ensure durability.

The literature tends to agree on that geopolymer mortars remain structurally sound for longer than PC materials under frost and wet-dry cycling. Several authors have determined a superior resistance for AA slag materials subject to wet-dry cycling [29, 30] and freeze-thaw cycling [31]. Fu et al. [31] evidenced weight loss under $1 \%$ a frost resistance coefficient of $\sim 90 \%$ after 300 cycles. It is also relatively common to find instances of strength increase following durability cycling in the literature [32-35].

In summary, as it can be seen from the above, research indicates that AA slag materials display a high resistance to aggressive conditions, and that they can remain structurally intact, without any 
expansion or material loss, for longer than PC materials. However, variability in the chemical composition of the slag might have an effect on durability, and AA materials prepared using different slags might have different resistance to aggressive conditions [20].

This research intends to determine whether AA materials made with a Dublin slag are as resistant as those reported in the literature. The slag was characterized in former papers. The slag was activated with sodium hydroxide $(\mathrm{NaOH})$ and sodium silicate $\left(\mathrm{Na}_{2} \mathrm{SiO}_{3}\right)$, both combined and separately. The resistance of the resultant materials to thermal and moisture cycles, frost action and salt crystallization was determined by studying strength and mass loss, as well as macro and microstructural changes after performing accelerated weathering tests in the laboratory. This paper studies the evolution of strength over time and after induced weathering, as well as the products of degradation and microstructural changes of materials made with an alkali-activated slag (AAS).

\section{Materials and Methods}

\subsection{Physical Properties and Composition of the GGBS}

GGBS is a vitreous material formed by rapid cooling of a melt of iron ore in a blast furnace. It usually consists of at least two thirds by mass of glassy slag, showing hydraulic properties when suitably activated [36]. The GGBS studied is produced in Ringsend, Dublin, with raw molten slag imported from Europe, and it was characterized in a former study by Alelweet and Pavia [23]. The particle size distribution was measured by laser diffraction. The specific surface of the particles was calculated with the BET (Brunauer-Emmett-Teller) method. The chemical composition was determined by X-ray fluorescence (XRF) as a percentage by oxide, and the loss on ignition (LOI) measured as weight loss by calcination. As the slag was highly amorphous, thermal treatments were used to cause phase transformation (devitrification) and hence investigate the amorphous phases in the slag. The mineral assemblage in the slag was studied with X-Ray Diffraction (XRD). The analyses were carried out using the powder method, with a Phillips PW1720 XRD diffractometer furnished with a PW1050/80 goniometer and a PW3313/20 Cu k-alpha anode tube. All measurements were taken at $40 \mathrm{kV}$ and $20 \mathrm{~mA}$.

\subsection{Activation of the GGBS and Mixing of the Alkali-Activated Slag (AAS) Mortars}

The advantage of using GGBS as a precursor to produce AA cements is that it requires a lower alkaline activator concentration (2-8\%) than other precursors such as fly ash [37].

$\mathrm{Na}_{2} \mathrm{SiO}_{3}$ and $\mathrm{NaOH}$ are the most common activators.

The GGBS was activated with $\mathrm{NaOH}$ and $\mathrm{Na}_{2} \mathrm{SiO}_{3}$, both combined and separately. The $\mathrm{NaOH}$ comes in solid form and the silicate as a commercial solution. First, the solid $\mathrm{NaOH}$ was dissolved in water to obtain an $8 \mathrm{M}$ alkaline solution. The concentration was chosen based on background research. When the alkali and the slag are mixed, the $\mathrm{pH}$ controls reactivity because it determines the slag's dissolution. A high $\mathrm{pH}$ is not adequate for Ca-rich precursors such as the GGBS in this research, because at very high $\mathrm{OH}^{-}$concentrations, although $\mathrm{Si}$ and $\mathrm{Al}$ increase solubility $\mathrm{Ca}$ becomes less soluble [38]. Furthermore, high concentrations of hydroxide activator in slag materials promote efflorescence $[25,38]$. Hence, high $\mathrm{Ca}$ slags ( $\mathrm{Ca}=35-45 \%)$ are usually activated under moderated alkaline conditions $[9,15,39]$. The objective of mixing the $\mathrm{Na}_{2} \mathrm{SiO}_{3}$ with the $\mathrm{NaOH}$ activator was to provide extra $\mathrm{Si}$ ions in the activation process to enhance mechanical 
properties. The silicate modulus is $1.92\left(\mathrm{SiO}_{2} / \mathrm{Na}_{2} \mathrm{O}\right)$ and the ratio $\mathrm{Na}_{2} \mathrm{SiO}_{3} / \mathrm{NaOH}=1.5$. An increase in the ratio of $\mathrm{Na}_{2} \mathrm{SiO}_{3} / \mathrm{NaOH}$ by mass usually increases the compressive strength of the resultant AA material [40-42]. Das et al. [43] suggest an optimum ration value of 1.5 to enhance compressive strength. Therefore, the $\mathrm{Na}_{2} \mathrm{SiO}_{3} / \mathrm{NaOH}$ activator was prepared, at a mass ratio of 1.5 to enhance compressive strength.

The alkali solution / GGBS $=0.48-0.60$ by weight (Table 2 ) is the ratio between the liquid alkaline solution (including water content) and the solid GGBS that provided a good workability as determined with the initial flow test. As it can be seen from the table, the silica activator required significant additional water due to its viscosity. The amount of alkali solution required for the mixes to provide a suitable workability for handling and placing (approximately 160-170 mm initial flow diameter) was measured using a flow table according to EN 1015-3 [44].

Table 2 Composition of the AA slag materials.

\begin{tabular}{lllllc}
\hline Mortar & $\begin{array}{l}\text { GGBS } \\
(\mathrm{g})\end{array}$ & Sand (g) & $8 \mathrm{MNaOH}(\mathrm{g})$ & $\begin{array}{l}\mathrm{Na}_{2} \mathrm{SiO}_{3} \\
(\mathrm{~g})\end{array}$ & $\begin{array}{c}\text { WATER+Alkali solution } \\
\text { /GGBS }\end{array}$ \\
\hline $\begin{array}{l}\mathrm{Na}_{2} \mathrm{SiO}_{3} / \mathrm{NaOH} \\
\text { activated }\end{array}$ & 500 & 1500 & 94 & 141 & 0.48 \\
$\mathrm{NaOH}$ activated & 500 & 1500 & 235 & 0 & 0.48 \\
$\mathrm{Na}_{2} \mathrm{SiO}_{3}$ activated & 500 & 1500 & 0 & 300 & 0.60 \\
\hline
\end{tabular}

The GGBS and sand were dry mixed at a ratio of 1 to 3 . The alkaline solution was then added and mixed for a further 5 mins. As expected from the previous literature, the $\mathrm{NaOH}$ was the most viscous and $\mathrm{Na}_{2} \mathrm{SiO}_{3}$ the stickiest activator. The moulds were filled and vibrated, and then sealed with a plastic sheet to prevent the loss of moisture during curing. The specimens were demoulded after 24 hours and cured in ambient conditions for a further 24 hours. After this, some of the specimens were cured in an oven, at $60^{\circ} \mathrm{C}$ for $24 \mathrm{~h}$, and in ambient conditions for the rest of the time. The curing temperature was raised as a catalyzer for alkali reactions to occur however, it was kept under $100^{\circ} \mathrm{C}$ due to environmental concerns.

\subsection{Accelerated Weathering Tests}

Accelerated weathering tests do not mimic real conditions but are more aggressive than most natural environments. Nevertheless, they provide an indication of the resistance of a materials to the repeated action of the main weathering agents, informing on the resilience of a material to salt crystallization, moisture, temperature and frost action. In total, 144 prismatic $(40 \times 40 \times 160 \mathrm{~mm})$ specimens were produced to test strength development and perform accelerated weathering test including thermal, freeze-thaw and salt crystallization cycles. 54 specimens were tested for flexural strength ( 3 specimens of each mix (3) for each test ( 3 cycles) at each temperature (2)) and the same for compressive strength. In addition, 36 control specimens (no cycling) were tested, 3 for each test at each temperature.

The resistance to salt attack was evaluated by performing 20 salt crystallization cycles according to International RILEM recommendations [45]. The samples were immersed in a $14 \%$ solution of sodium sulphate decahydrate $\left(\mathrm{Na}_{2} \mathrm{SO}_{4} \cdot 10 \mathrm{H}_{2} \mathrm{O}\right)$ for $4 \mathrm{~h}$. The density of this solution at $20{ }^{\circ} \mathrm{C}$ is 1055 
$\mathrm{kg} / \mathrm{m}^{3}$. They were then removed and left to dry in an oven pre-heated to $105^{\circ} \mathrm{C}$ for 15 hours and later left to cool to room temperature for 6 hours. Their individual masses were noted before recommencement of the soaking phase.

The resistance to deterioration induced by thermal and moisture expansion was assessed by performing 25 wet-dry cycles. The specimens were immersed in water at a constant temperature of $20 \pm 0.5^{\circ} \mathrm{C}$ for 16 hours and dried in an oven pre-heated to $105^{\circ} \mathrm{C}$ for 6 hours.

The resistance to frost-induced damage was measured by performing 20 freeze-thaw cycles according to EN 15304:2010 [46]. As the temperature lowers the water held in the capillary pores freezes and expansion occurs, causing cracking and scaling. The specimens were immersed in water at constant temperature $\left(20 \pm 0.5^{\circ} \mathrm{C}\right)$ for 6 hours and then moved to a freezer at $-20^{\circ} \mathrm{C}$ temperature for 15 hours.

\subsection{Assessment of the Durability}

The extent of the damage caused by the accelerated weathering tests was evaluated by monitoring the mass loss, compressive and flexural strength loss and microscopic and macroscopic damage after performing the cycles in the laboratory. After each cycle, the condition of the specimens was noted, and the results reported in terms of weight loss (expressed as a percentage of the initial dry weight). The mass loss and residual compressive strength were determined on completion of the cycling. The compressive strength was measured before and after performing the cycles in accordance with EN1015-11 [47], using a ZWICK 1474 machine of 100 kN loading capacity, at a loading rate of $10 \mathrm{~N} / \mathrm{s}$. The results reported are the arithmetic mean of six tests.

\subsection{Assessment of the Microstructure}

The microstructure of the materials was assessed with a scanning electron microscope (SEM). Qualitative analyses focussed on the cement. Specimens sized approximately $1 \mathrm{~cm}^{3}$ were embedded in epoxy resin and Carbon-coated to provide observation surfaces of approximately $1.5 \mathrm{~cm}^{2}$. SEM micrographs and elemental chemical composition spectrums were acquired, at 5- $20 \mathrm{KV}$, using an SE2 detector with a SEM microscope. The elemental chemical composition spectrums were acquired with an energy dispersive X-ray microanalysis (EDXR) system consisting of an Oxford INCA X Max detector which acquired elemental composition spectra of specific mineral phases and general areas in the matrix.

\section{Results}

\subsection{Physical Properties and Composition of the GGBS}

The physical properties of the alkali activated GGBS including specific surface area, particle size, density and loss on ignition are compared with those of cement, and a fly ash (FA) which, according to Alelweet and Pavia [48], is deemed suitable for alkali activation (table 3). As it can be seen from table 3, the GGBS particles are lighter and finer than the FA particles $\left(1.80 \mathrm{vs} 2.28 \mathrm{mg} / \mathrm{m}^{3}\right)$, and have a greater specific surface area than CEM II. The LOI values indicate that the GGBS particles are dehydrated and that they contain neither organic matter nor carbonates. 
Table 3 Specific surface area, particle size, density and loss on ignition (LOI) of the GGBS compared with FA and CEM II /A-L 32, 5N (6-20\% limestone and 5\% minor addition) [48].

\begin{tabular}{|c|c|c|c|c|c|c|c|c|c|}
\hline & \multirow{2}{*}{$\begin{array}{l}\text { specific } \\
\text { surface area } \\
\text { (SSA) } \mathrm{m}^{2} / \mathrm{g}\end{array}$} & \multirow{2}{*}{$\begin{array}{l}\text { specific } \\
\text { surface area } \\
\text { (SSA) } \mathrm{m}^{2} / \mathrm{kg}\end{array}$} & \multirow{2}{*}{$\begin{array}{l}\text { particle } \\
\text { density } \\
\mathrm{mg} / \mathrm{m}^{3}\end{array}$} & \multicolumn{2}{|c|}{ Particle Size } & \multirow[b]{2}{*}{$\begin{array}{l}\text { D50 } \\
\mu \mathrm{m}\end{array}$} & \multirow[b]{2}{*}{$\begin{array}{l}\text { D10 } \\
\mu \mathrm{m}\end{array}$} & \multicolumn{2}{|l|}{ LOI (\%) } \\
\hline & & & & $\begin{array}{l}\text { mean } \\
\mu \mathrm{m}\end{array}$ & $\begin{array}{l}\text { D90 } \\
\mu \mathrm{m}\end{array}$ & & & $450^{\circ} \mathrm{C}$ & $1000^{\circ} \mathrm{C}$ \\
\hline \multirow{2}{*}{ FLY ASH } & \multirow{2}{*}{6.50} & \multirow{2}{*}{6500} & \multirow{2}{*}{2.28} & \multicolumn{4}{|c|}{0.20 to 650} & 1.67 & 4.92 \\
\hline & & & & 15 & 100.63 & 14.96 & 1.95 & & \\
\hline \multirow{2}{*}{ GGBS } & \multirow{2}{*}{1.95} & \multirow{2}{*}{1950} & \multirow{2}{*}{1.80} & \multicolumn{2}{|c|}{0.25 to 75} & & & 0.41 & -0.77 \\
\hline & & & & 18 & 31.62 & 11.67 & 2.35 & & \\
\hline CEM II & 1.88 & 1880 & - & - & 82.58 & 24.90 & 2.56 & - & - \\
\hline
\end{tabular}

The chemical composition of the GGBS, represented as oxides (in \% by weight), is included in table 4. Two samples were analysed several months apart to ensure reliability. As it can be seen from the results, the slag consists of mainly calcium (42\%) and silicon (32\%) with smaller aluminium (12\%).

Table 4 Chemical composition of the GGBS by X-Ray Fluorescence, expressed as \% by weight.

\begin{tabular}{|c|c|c|c|c|c|c|c|c|c|c|c|c|c|c|}
\hline & $\mathrm{SiO}_{2}$ & $\mathrm{Al}_{2} \mathrm{O}_{3} \mathrm{CaO}$ & $\mathrm{Fe}_{2} \mathrm{O}_{3}$ & $\mathrm{Na}_{2} \mathrm{O}$ & $\mathrm{K}_{2} \mathrm{O}$ & MgO & $\mathrm{P}_{2} \mathrm{O}_{5}$ & $\mathrm{SO}_{3}$ & $\mathrm{Cl}$ & $\mathrm{TiO}_{2}$ & $\mathrm{MnO}$ & CuO & Sro & $\mathrm{ZrO}_{2}$ \\
\hline GGBS & 31.71 & 10.8344 .90 & 0.51 & 0.03 & 0.71 & 7.50 & 0.42 & 2.08 & 0.03 & 0.95 & 0.17 & 0.00 & 0.07 & 0.05 \\
\hline GGBS $^{b}$ & 34.14 & 13853927 & 011 & 0.00 & 0.26 & 8.63 & 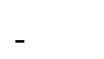 & 2.43 & 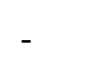 & 0.54 & 0.25 & & - & . \\
\hline $\begin{array}{l}\text { GGBS } \\
\text { mean }\end{array}$ & 32.00 & 1200120 & 0.45 & 0.03 & 0.50 & 8.00 & 0.42 & 2.20 & 0.03 & 0.75 & 0.20 & 0.00 & 0.07 & 0.05 \\
\hline
\end{tabular}

The properties and composition of the GGBS were compared with the standard requirements in EN 15167-1 for a GGBS to qualify as PC substitution. As it can be seen from table 5, the GGBS complies with the standard requirements for a GGBS to be deemed suitable for PC substitution in mortars, concretes and grouts. In addition, the alumina content of the slag complies with the high resistance (+SR) PC concrete designation for aggressive ground conditions (BS 8500) which stipulates that the alumina content of the GGBS should be below $14 \%$ if the $C_{3} A$ (tricalcium aluminate) content of the CEM I used in combination with the GGBS is high (above $10 \%$ ).

Table 5 Properties and composition of the GGBS compared with the standard requirements in EN 15167-1 and BS 8500-1: 2015 [49] for a GGBS to qualify as PC substitution [23].

\begin{tabular}{lll}
\hline & GGBS & $\begin{array}{l}\text { EN 15167-1 requirements for GGBS to qualify as PC } \\
\text { substitution }\end{array}$ \\
\hline $\mathrm{CaO}+{\mathrm{MgO} / \mathrm{SiO}_{2}}$ & $42+8 / 32=$ & $>1$ \\
$\mathrm{CaO}+\mathrm{MgO}+\mathrm{SiO}_{2}$ & 1.56 & $\geq 2 / 3(\approx 66 \%)$ \\
$\mathrm{Al}_{2} \mathrm{O}_{3}$ & $12 \%$ & $<14 \%$ if the $\mathrm{C}_{3} \mathrm{~A}$ content of the CEM I used in combination \\
& & with the GGBS is over $10 \%$ (BS $8500-1: 2015)$ \\
\hline
\end{tabular}




\begin{tabular}{lll}
\hline $\begin{array}{l}\text { Specific surface area- } \\
\text { SSA }\end{array}$ & $1950 \mathrm{~m}^{2} / \mathrm{kg}$ & Fineness: SSA $\geq 275 \mathrm{~m}^{2} / \mathrm{kg}$ \\
Unburned carbon & $0.41 \%$ & $\leq 3 \%-3.5 \%$ single result limit value \\
Chloride & $0.03 \%$ & $\leq 0.10 \%$ \\
Sulphate $\left(\mathrm{SO}_{3}\right)$ & $2.20 \%$ & $\leq 2.50 \%$ \\
MgO & $8 \%$ & $\leq 18 \%$ \\
\hline
\end{tabular}

The XRD analysis evidenced that nearly the total mass of the GGBS is amorphous (figure 1), hence no crystalline phases were identified with XRD analyses. The marked amorphousness of the GGBS (figure 1) means that the total silica plus alumina determined with XRF (which equals approximately $44 \%$ of the total oxide mass- table 3 ) are reactive.

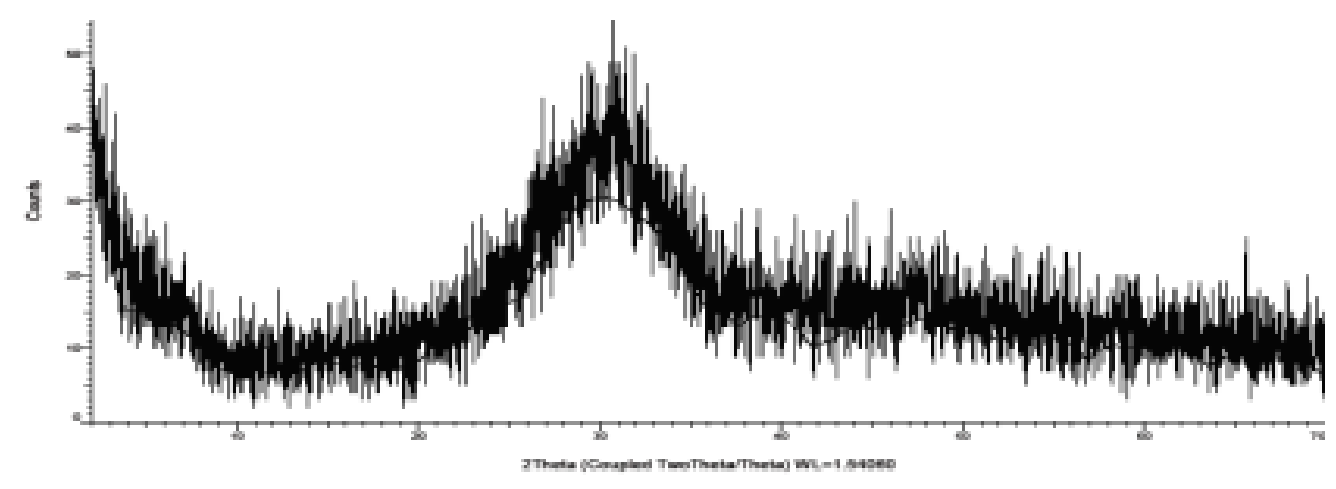

Figure 1 XRD trace of the GGBS consisting of amorphous material with no crystalline phases.

The devitrification experiment reveled the mineral composition of the GGBS [23]. According to the devitrification experiment, the GGBS consists of a solid solution of polymorphs Merwinite (PDF 00-035-0591) and Gehlenite (PDF 04-015-2993) (figure 2).
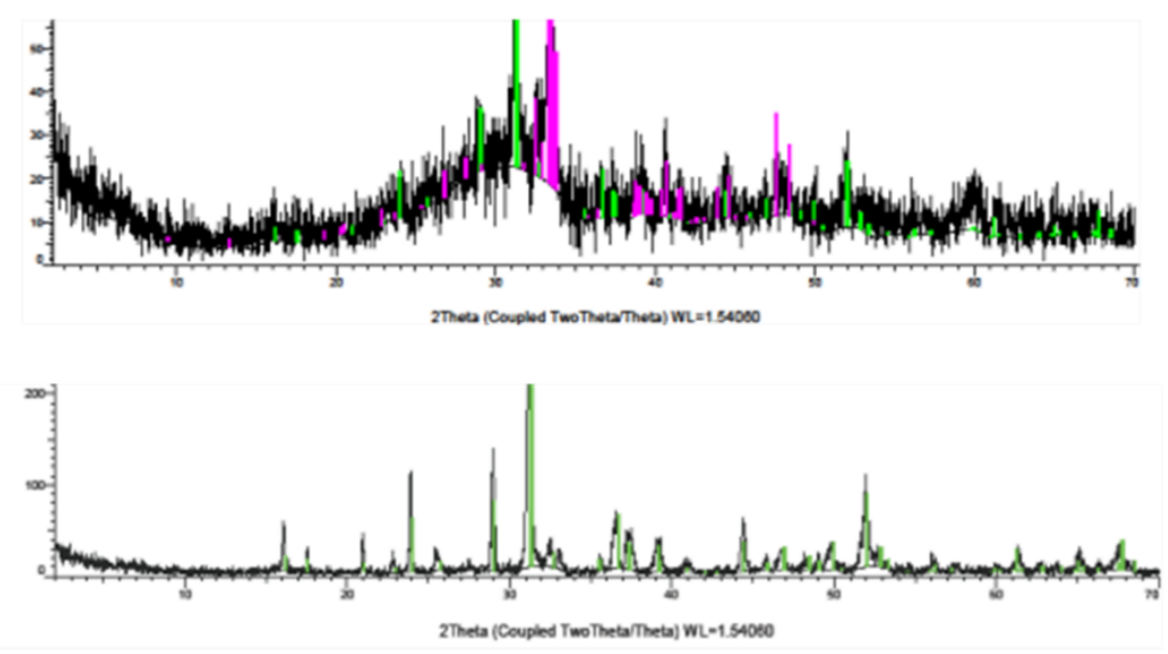

Figure 2 The XRD trace of the GGBS calcined at $800^{\circ} \mathrm{C}$ (top graph), indicates that an amorphous phase coexists with crystalline Gehlenite, PDF 04-015-2993 - Na0.05 $\mathrm{Ca}_{1.96}$ $\mathrm{Mg}_{0.24} \mathrm{Fe}_{0.12} \mathrm{Al}_{1.25} \mathrm{Si}_{1.39} \mathrm{O}_{7-}$ green peaks-, and Merwinite, PDF 00-035-0591- $\mathrm{Ca}_{3} \mathrm{Mg}$ ( $\mathrm{Si}$ $\left.\mathrm{O}_{4}\right)_{2}$ - pink peaks-. 
At $1000^{\circ} \mathrm{C}$ (bottom graph), the GGBS is crystalline, a perfect match to PDF 04-015-2993 - Na 0.05 $\mathrm{Ca}_{1.96} \mathrm{Mg}_{0.24} \mathrm{Fe}_{0.12} \mathrm{Al}_{1.25} \mathrm{Si}_{1.39} \mathrm{O}_{7-}$ Gehlenite.

\subsection{Strength of the AA GGBS Materials}

In most instances, the strength tends to increase significantly between 28 and 270 days (Table 6). This strength increase at late ages agrees with some authors such as Rodrigues et al. [26] who found strength increase up to 120 days, but does not conform with Collins and Sanjayan [16] who found that the strength of alkali activated slag concrete tends to reduce at late ages (360 days), and attributed the reduction to the occurence of a network of interconnected microcracks with increasing age. 
Table 6 Long-term evolution of the mechanical properties of the AA, GGBS materials: effect of increasing curing temperature and age. 3:1 (sand: GGBS); $\mathrm{Na}_{2} \mathrm{SiO}_{3} / \mathrm{NaOH}=1.5 ; 8 \mathrm{M} \mathrm{NaOH}$.

\begin{tabular}{|c|c|c|c|c|c|c|c|c|c|c|c|c|}
\hline \multirow{3}{*}{ Days } & \multicolumn{4}{|c|}{$\mathrm{Na}_{2} \mathrm{SiO}_{3}+\mathrm{NaOH}$ activated } & \multicolumn{4}{|c|}{$\mathrm{NaOH}$ activated } & \multicolumn{4}{|c|}{$\mathrm{Na}_{2} \mathrm{SiO}_{3}$ activated } \\
\hline & \multicolumn{2}{|c|}{$\begin{array}{l}\text { Flexural strength } \\
\text { COVs }=0.05-0.08\end{array}$} & \multicolumn{2}{|c|}{$\begin{array}{l}\text { Compressive strength } \\
\text { COVs }=0.00-0.48\end{array}$} & \multicolumn{2}{|c|}{$\begin{array}{l}\text { Flexural strength } \\
\text { COVs }=0.00-0.20\end{array}$} & \multicolumn{2}{|c|}{$\begin{array}{l}\text { Compressive strength } \\
\text { COVs }=0.00-0.08\end{array}$} & \multicolumn{2}{|c|}{$\begin{array}{l}\text { Flexural strength } \\
\text { COVs }=0.01-0.41\end{array}$} & \multicolumn{2}{|c|}{ Compressive strength } \\
\hline & $20^{\circ} \mathrm{C}$ & $60^{\circ} \mathrm{C}$ & $20^{\circ} \mathrm{C}$ & $60^{\circ} \mathrm{C}$ & $20^{\circ} \mathrm{C}$ & $60^{\circ} \mathrm{C}$ & $20^{\circ} \mathrm{C}$ & $60^{\circ} \mathrm{C}$ & $20^{\circ} \mathrm{C}$ & $60^{\circ} \mathrm{C}$ & $20^{\circ} \mathrm{C}$ & $60^{\circ} \mathrm{C}$ \\
\hline 270 & 7.01 & 7.26 & 93.06 & 94.36 & 5.62 & 8.26 & 61.11 & 65.31 & 5.70 & 3.05 & 32.79 & 24.63 \\
\hline $\begin{array}{l}\% \text { change } \\
28-270 d\end{array}$ & +12 & +2 & +72 & +64 & +86 & +80 & +71 & +81 & +66 & -6 & +84 & +88 \\
\hline
\end{tabular}


Raising the curing temperature enhances the strengths of the $\mathrm{Na}_{2} \mathrm{SiO}_{3}+\mathrm{NaOH}$ activated slag at all ages (table 6), however the strength increase is small except for the 28-day compressive strength that increases by $23 \%$. The results agree with previous authors reporting that, at ages up to 28 days, the increase of curing temperature slightly enhances mechanical strength when the activator is $\mathrm{Na}_{2} \mathrm{SiO}_{3}+\mathrm{NaOH}[9,19]$. At early ages (up to 28 days) increasing curing temperature also enhances the flexural strengths of the $\mathrm{NaOH}$ and $\mathrm{Na}_{2} \mathrm{SiO}_{3}$ activated slags but lowers their compressive strengths. At late ages (270 days) increasing curing temperature enhances the strengths of all the specimens except for the $\mathrm{Na}_{2} \mathrm{SiO}_{3}$ activated slags. This disagrees with Bakharev at al. [10] who report that heat initially accelerates the strength development of AAS concrete, but at later ages, the compressive strength is reduced when compared with room temperature. However, the results agree with San Nicolas et al. [21]. The strength variation triggered by the higher curing temperature is within the values reported by San Nicolas et al. [21] who studied the performance of AA slag materials up to the age of 540 days and report total strength variations of around $5 \mathrm{MPa}$, and no significant strength variation with increasing curing temperatures $\left(20-60^{\circ} \mathrm{C}\right)$. The results disagree with Qureshi and Ghosh [22] who studied the influence of curing at $40-60{ }^{\circ} \mathrm{C}$ on the mechanical properties of AA slag concrete concluding that the optimum temperature of $50{ }^{\circ} \mathrm{C}$ provided the highest compressive strength of $36.50 \mathrm{MPa}$ at 28 days.

Altan and Erdoğan [19] state that a $\mathrm{NaOH}$ activator performs best at room temperature, since temperature affects amount and rate of slag dissolution so that, at higher temperature, slag dissolution is sufficient and $\mathrm{NaOH}$ activation is not needed for strength gain. However, only the compressive strength results at 28 days agree with these authors, because it is only in this instance that the $\mathrm{NaOH}$ activator performs better at room temperature.

As aforementioned, at 270 days, increasing curing temperature enhances the strengths of all the specimens except for the $\mathrm{Na}_{2} \mathrm{SiO}_{3}$ activated slags. Yet, the tendency is that the increase is not significant agreeing with former literature $[9,50]$. However, the $\mathrm{NaOH}$-activated slag is an exception, as increasing the curing temperature doubles its flexural strength at 28 days and increases it by c. $25 \%$ at 270 days, similarly, the 270 -day compressive strength rises by c. $6 \%$.

\subsection{Effect of Accelerated Weathering on the Mechanical Strength of AAS Materials}

It was expected that the AAS materials would loose some strength as a result of weathering but the results are inconsistent, and the stregths after weathering are sometimes higher than before (table 7). This agrees with former authors: Bakharev et al. [20], following experiments with sodium sulfate solutions, found strength increase in AAS concrete. Similarly, Luga [29] evidenced that slag geopolymers increased compressive strength by $14-24 \%$ respectively following wet-dry cycles, and other authors found a compressive strength increase after freeze-thaw cycling [32-33, 35]. The strength increase can be attributed to the presence of smaller pores [34] but is is likely the result of continuing hydration [20].

Raising the curing temperature does not seem to increase durability, as the strength losses of the room-cured specimens after cycling are comparable to those cured at high temperature. No consistent trend was found in order to determine whether a certain weathering agent undermines the AA materials further than other, as the strength losses after the three types of cycles are comparable. The $\mathrm{Na}_{2} \mathrm{SiO}_{3}+\mathrm{NaOH}$ activated GGBS specimens lost the least strength as a result of performing durability cycles. 
Table 7 Effect of accelerated weathering on the 270 day strength of the AAS materials (MPa).

\begin{tabular}{|c|c|c|c|c|c|c|c|c|c|c|c|c|}
\hline & \multicolumn{4}{|c|}{$\mathrm{Na}_{2} \mathrm{SiO}_{3} / \mathrm{NaOH}$ activated } & \multicolumn{4}{|c|}{$\mathrm{NaOH}$ activated } & \multicolumn{4}{|c|}{$\mathrm{Na}_{2} \mathrm{SiO}_{3}$ activated } \\
\hline & \multicolumn{2}{|c|}{ Flexural strength } & \multicolumn{2}{|c|}{$\begin{array}{l}\text { Compressive } \\
\text { strength }\end{array}$} & \multicolumn{2}{|c|}{ Flexural strength } & \multicolumn{2}{|c|}{$\begin{array}{l}\text { Compressive } \\
\text { strength }\end{array}$} & \multicolumn{2}{|c|}{ Flexural strength } & \multicolumn{2}{|c|}{$\begin{array}{l}\text { Compressive } \\
\text { strength }\end{array}$} \\
\hline & $20^{\circ} \mathrm{C}$ & $60^{\circ} \mathrm{C}$ & $20^{\circ} \mathrm{C}$ & $60^{\circ} \mathrm{C}$ & $20^{\circ} \mathrm{C}$ & $60^{\circ} \mathrm{C}$ & $20^{\circ} \mathrm{C}$ & $60^{\circ} \mathrm{C}$ & $20^{\circ} \mathrm{C}$ & $60^{\circ} \mathrm{C}$ & $20^{\circ} \mathrm{C}$ & $60^{\circ} \mathrm{C}$ \\
\hline Wet-dry & 6.75 & 8.97 & 93.06 & 91.83 & 4.69 & 5.25 & 61.11 & 71.91 & 1.41 & 8.09 & 17.97 & 32.45 \\
\hline $\begin{array}{l}\text { Salt } \\
\text { crystallization }\end{array}$ & 5.13 & 6.47 & 96.34 & 98.68 & 5.06 & 7.05 & 65.31 & 74.76 & 4.60 & 6.57 & 8.24 & 25.88 \\
\hline Freeze-thaw & 5.51 & 6.59 & 77.43 & 87.41 & 3.56 & 2.47 & 38.50 & 40.33 & 0.54 & 3.06 & 20.40 & 16.63 \\
\hline $\begin{array}{l}\text { Control (no } \\
\text { cycles) }\end{array}$ & 7.01 & 7.26 & 93.06 & 94.36 & 5.62 & 8.26 & 61.11 & 65.31 & 5.70 & 3.05 & 32.79 & 24.63 \\
\hline covs & $\begin{array}{l}0.04- \\
0.35\end{array}$ & $\begin{array}{l}0.04- \\
0.10\end{array}$ & $\begin{array}{l}0.05- \\
0.50\end{array}$ & $\begin{array}{l}0.03- \\
0.10\end{array}$ & $\begin{array}{l}0.07- \\
0.17\end{array}$ & $\begin{array}{l}0.02- \\
0.13\end{array}$ & $\begin{array}{l}0.02- \\
0.45\end{array}$ & $\begin{array}{l}0.02- \\
.0 .17\end{array}$ & $\begin{array}{l}0.00- \\
0.68\end{array}$ & $\begin{array}{l}0.09- \\
0.24\end{array}$ & $\begin{array}{l}0.06- \\
0.50\end{array}$ & $\begin{array}{l}0.15- \\
0.30\end{array}$ \\
\hline
\end{tabular}




\subsection{Macroscopic Damage and Mass Loss Induced by Accelerated Weathering}

Salt-crystallization cycling. The $\mathrm{Na}_{2} \mathrm{SiO}_{3}+\mathrm{NaOH}$ activated GGBS showed the best durability after salt crystallization cycling. Some specimens lost/gained a small amount of mass (table 8). However, no damage appeared after cycling. The $\mathrm{Na}_{2} \mathrm{SiO}_{3}$ activated GGBS lost insignificant material after 20 salt crystallization cycles. However, several specimens showed microcracks with no expansion or displacement and efflorescence (figure 3). The $\mathrm{NaOH}$ activated GGBS displays the worst resistance to salt-induced damage, with efflorescence and slight swelling appearing after 15 cycles, and c.3\% mass gain probably linked to the absorption and retention of salt solution inside voids and cracks (figure 4).

Table 8 Mass loss of AAS materials after salt crystallization cycling.

\begin{tabular}{llll}
\hline & Mass loss (\%) after salt cycling & & \\
& $\mathrm{Na}_{2} \mathrm{SiO}_{3}+\mathrm{NaOH}$ activated & $\mathrm{NaOH}$ activated & $\mathrm{Na}_{2} \mathrm{SiO}_{3}$ activated \\
\hline Cured at $20^{\circ} \mathrm{C}$ & -1.53 & 3.55 & -0.33 \\
Cured at $60^{\circ} \mathrm{C}$ & 1.78 & 2.98 & -0.36 \\
\hline
\end{tabular}
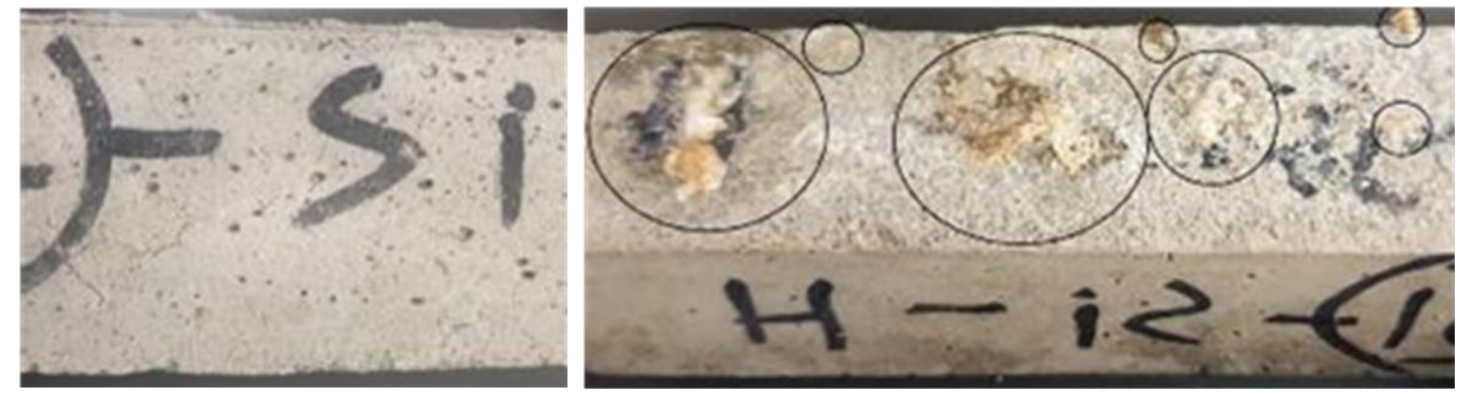

Figure $3 \mathrm{Na}_{2} \mathrm{SiO}_{3}$ activated GGBS after salt crystallization cycles. Left: Microcracks in the $20^{\circ} \mathrm{C}$ - cured specimens. Right: efflorescence in the $60^{\circ} \mathrm{C}$-cured specimens.

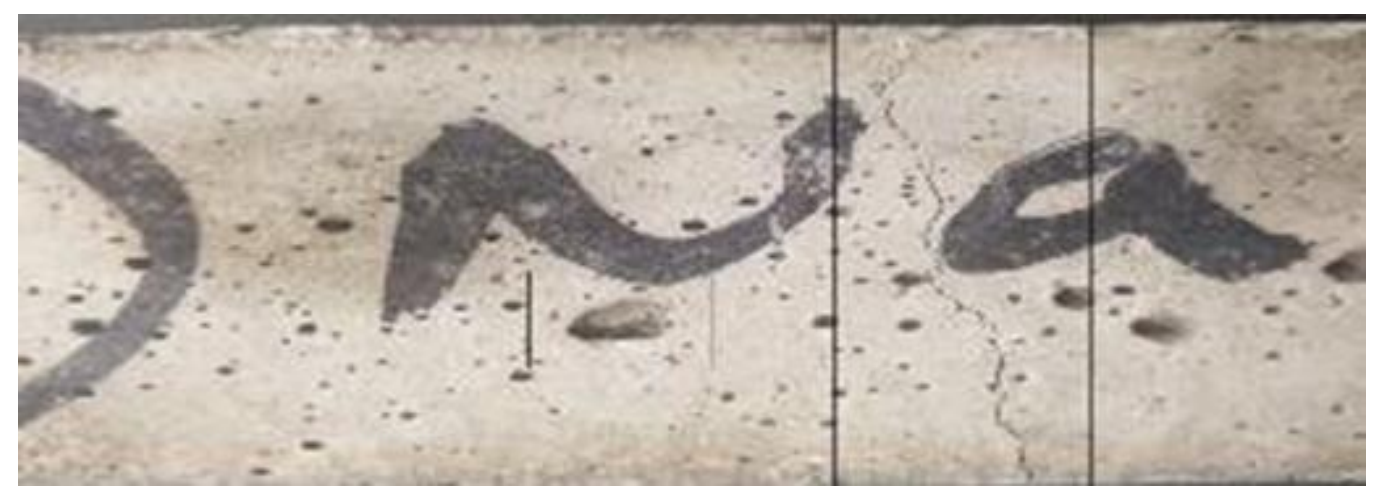

Figure $4 \mathrm{NaOH}$ activated $\mathrm{GGBS}, 60^{\circ} \mathrm{C}$-cured, after salt crystallization cycling showing cracks.

As aforementioned, the intensity of sulphate attack has been related to the alumina content. The alumina content of the GGBS is c.12\% wt which complies with the BS 8500 requirements for a highresistance (+SR) PC concrete for aggressive ground conditions. It is a similar content to other slags, but slightly higher than many PCs (usually 4-6\%, the majority below $10 \%$ ). Nevertherless, no gypsum 
or ettringite were recorded with the SEM (See section 3.5 Microstructure and microscopic damage). In the AA materials investigated, the slag is the only source for alumina therefore the content is within safe levels regarding durability.

Wet-dry cycling. The best durability after wet-dry cycling is shown by the $\mathrm{Na}_{2} \mathrm{SiO}_{3}+\mathrm{NaOH}$ activated GGBS cured at $60^{\circ} \mathrm{C}$ and $20^{\circ} \mathrm{C}$. The mass change (c.0.5\%) is insignificant, and the specimens showed virtually no alteration after cycling. The worst resistance to wet-dry cycling is shown by the $\mathrm{Na}_{2} \mathrm{SiO}_{3}$ activated GGBS which shows the greatest mass variation at c.4\% (table 9). Cracks and efflorescence appeared after 25 cycles (figure 5) indicating certain water absorption and retention.

Table 9 Mass loss of AAS specimens after thermal/moisture cycling.

\begin{tabular}{llll}
\hline & \multicolumn{2}{l}{ Mass loss (\%) after wet/dry cycling } & \\
& $\mathrm{Na}_{2} \mathrm{SiO}_{3}+\mathrm{NaOH}$ activated & $\mathrm{NaOH}$ activated & $\mathrm{Na}_{2} \mathrm{SiO}_{3}$ activated \\
\hline Cured at $20\left({ }^{\circ} \mathrm{C}\right)$ & 0.51 & 1.59 & -3.57 \\
Cured at $60\left({ }^{\circ} \mathrm{C}\right)$ & 0.42 & 0.86 & -4.13 \\
\hline
\end{tabular}
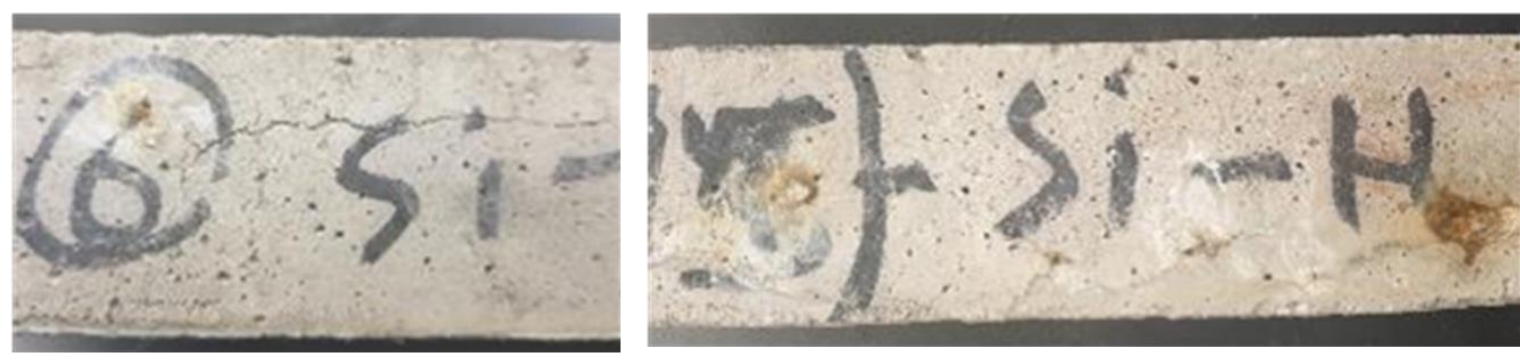

Figure $5 \mathrm{Na}_{2} \mathrm{SiO}_{3}$ activated GGBS after 25 wet-dry cycles. Left image $20{ }^{\circ} \mathrm{C}$ cured, right $60{ }^{\circ} \mathrm{C}$ cured showing cracks, delamination and slight efflorescence.

The literature tends to agree on that geopolymer mortars remain structurally intact without any visible cracks or deterioration for longer, while surface microcracks appear on PC mortars following dry-wet cycles. Djobo et al. [30] evidenced no visual deterioration after 25 wet-dry cycles in mortars made with an alkali activated volcanic ash, and small compressive strength reductions of $24 \%$ and $14 \%$ for specimens cured at $27^{\circ} \mathrm{C}$ and $80^{\circ} \mathrm{C}$ respectively. The results agree with Luga [29] who evidenced a high resistance to wet-dry cycles for slag/fly ash geopolymers, and an increase in compressive strength by $14 \%$ and $24 \%$ respectively for slag and fly ash/slag geopolymers.

Freeze-thaw cycling. The best durability after freeze-thaw cycling is shown by the $\mathrm{Na}_{2} \mathrm{SiO}_{3}+\mathrm{NaOH}$ activated GGBS with no degradation or efflorescence, and the highest mechanical strength (cured at $60^{\circ} \mathrm{C}$ )- table 10 . The $\mathrm{Na}_{2} \mathrm{SiO}_{3}$ activated GGBS cured at $60{ }^{\circ} \mathrm{C}$ showed the highest weight loss after 20 cycles, and the $\mathrm{NaOH}$-activated slag showed efflorescence (figure 6). It is well known that pore structure and saturation largely determine the amount of damage by frost action, as water held in pores and capillars expands on freezing, causing stresses and eventually disruption, which is usually evidenced as micro-cracks that eventually cause material detachment. The pore structure of these materials is the object of a future study. The results agree with Fu et al. [31] who showed experimentally that alkali-activated $\left(\mathrm{Na}_{2} \mathrm{SiO}_{3}, \mathrm{NaOH}\right)$ slag concrete has an excellent freeze-thaw resistance. They evidenced a high resistance, with slight weight loss $(<1 \%)$ after 300 cycles and a frost resistance coefficient of $\sim 90 \%$. 
Table 10 Mass loss of AAS specimens after freeze/thaw cycling.

\begin{tabular}{llll}
\hline \multicolumn{4}{c}{ Mass loss (\%) after freeze/thaw cycling } \\
& $\mathrm{Na}_{2} \mathrm{SiO}_{3}+\mathrm{NaOH}$ activated & $\mathrm{NaOH}$ activated & $\mathrm{Na}_{2} \mathrm{SiO}_{3}$ activated \\
\hline Cured at $20\left({ }^{\circ} \mathrm{C}\right)$ & -1.53 & -1.35 & -1.69 \\
Cured at $60\left({ }^{\circ} \mathrm{C}\right)$ & -1.41 & -1.90 & -3.76 \\
\hline
\end{tabular}

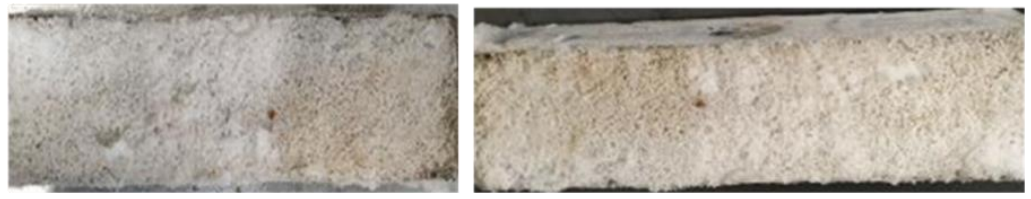

Figure 6 Efflorescence on $\mathrm{NaOH}$ activated GGBS after 20 freeze- thaw cycles (left $20^{\circ} \mathrm{C}$ cured; right $\left.60^{\circ} \mathrm{C}\right)$.

\subsection{Microstructure and Microscopic Damage}

Efflorescence appeared after salt crystallization, dry-wet and freeze-thaw cycling in most of the specimens that were $\mathrm{NaOH}$ and $\mathrm{Na}_{2} \mathrm{SiO}_{3}$ activated. The formation of efflorescence in AA materials is relatively common. It has been associated with high concentrations of hydroxide activator in slag materials [25, 38], and with the depolymerization of cementing hydrate gels at advanced times of curing. In AA materials, Ke et al. [51] linked the salt efflorescences to the loss alkali cations from the cementing hydrate gels. It has also been reported in the literature that unreacted sodium is mobile within the pore network, and that it is prone to the formation of efflorescence when in contact with atmospheric $\mathrm{CO}_{2}$ [52-57]. The tendency towards efflorescence in AAMs has also been related to a high alkali concentration in the pore solution [58] and to the relatively weak binding (and exchangeability) of the sodium in the aluminosilicate gel structure [59-61].

On hand samples, the salts show a similar powdery habit, and do not seem to be associated to expansion, cracking or bulging of the specimens. However, this was further investigated microscopically with an scanning electron microscope. Under the microscope, the salts appear to cover areas erratically, hence it was not possible to conclude whether they originate from the cementing gel or not. However, the elemental composition shows that the salts are mainly soda $\left(\mathrm{Na}_{2} \mathrm{O}\right)$ probably mixed with some sodium carbonates and sulphates (figures 7-10).

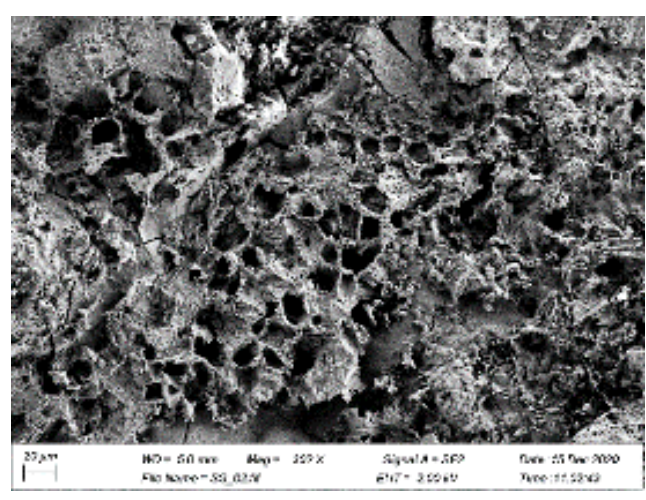

Figure 7 Alkali-activated GGBS after frost cycling, showing an area with erratic distribution of salt efflorescence. 


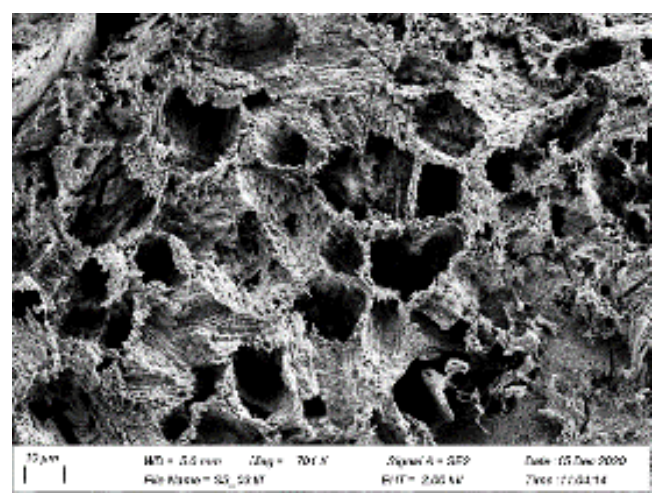

Figure 8 Detail of the salts in figure 7, their composition appears in figure 10.

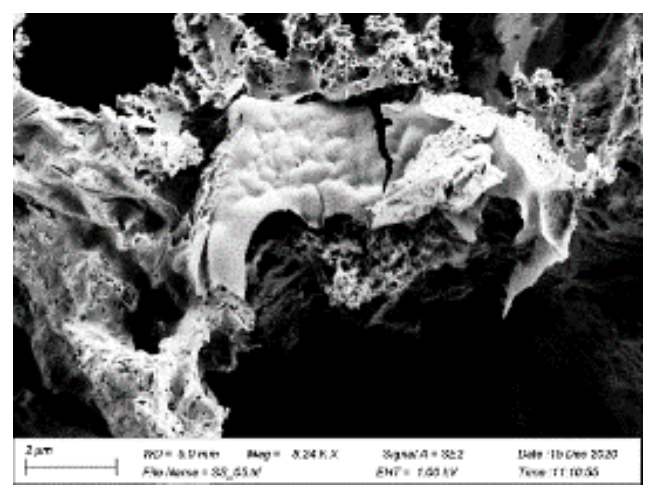

Figure 9 Detail of the salts after frost cycling.

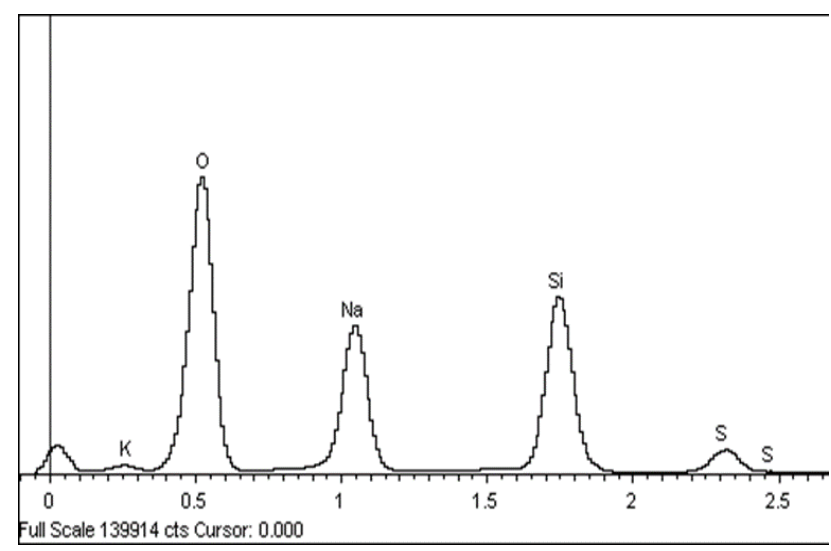

Figure 10 The elemental composition shows that the salt is mainly soda $\left(\mathrm{Na}_{2} \mathrm{O}\right)$ probably mixed with some sodium carbonates and sulphates.

Cracking due to drying shrinkage is one of the challenges for alkali-activated slag materials, and it increases as the lime content in the system lowers [15]. Hence the high Ca content of this slag has probably reduced drying-shrinkage cracking and contributed to the sound microstructure of the materials.

Sulfate damage to PC materials is usually associated to the presence of aluminates, as the reaction between sulfate and $\mathrm{PC}$ aluminates produces expansible ettringite and gypsum which lead to cracking and disruption, hence low aluminium PC materials have superior resistance to sulfate environments [24]. Despite the Al content in the slag (c.12\%) and the sulphur in the test solutions, neither expansive gypsum nor ettringite were recorded with the SEM. Hence, the salts can be partly attributed to the high alkalinity of the materials which, together with the high mobility of the sodium 
and the salt solution, have enable efflorescence to precipitate on the surface of the specimens. The SEM examination confirmed the superficial distribution and the lack of expansive cracks or bulging associated to the efflorescence (figures 7-9).

The microstructure of the best performers $\left(\mathrm{Na}_{2} \mathrm{SiO}_{3}+\mathrm{NaOH}\right.$ activated $\mathrm{GGBS}$ cured at $60^{\circ} \mathrm{C}$ after 270 days of curing) seems unaltered after cycling. It varies from areas consisting of unreacted GGBS particles and scattered silica cements (figures 11-13) to others featuring abundant silicates with different habits, mainly isometric and tabular (figure 14).

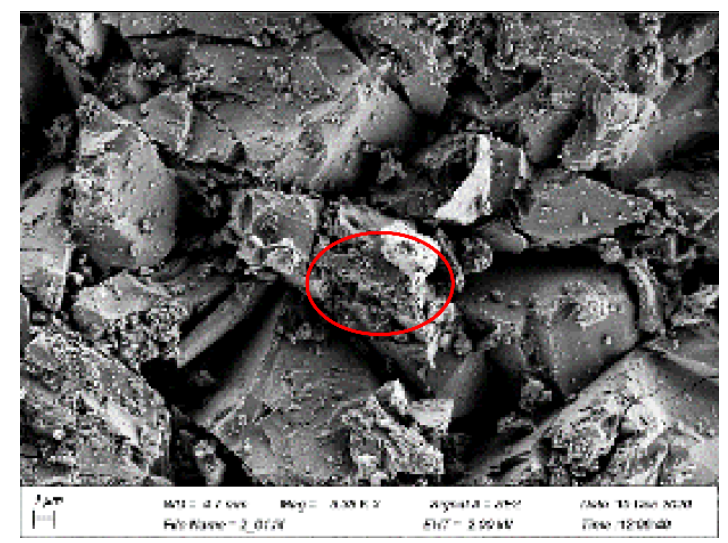

Figure 11 Microstructure of the $\mathrm{Na}_{2} \mathrm{SiO}_{3}+\mathrm{NaOH}$ activated GGBS cured at $60^{\circ} \mathrm{C}$ at 270 days showing unreacted GGBS particles and scattered cements.

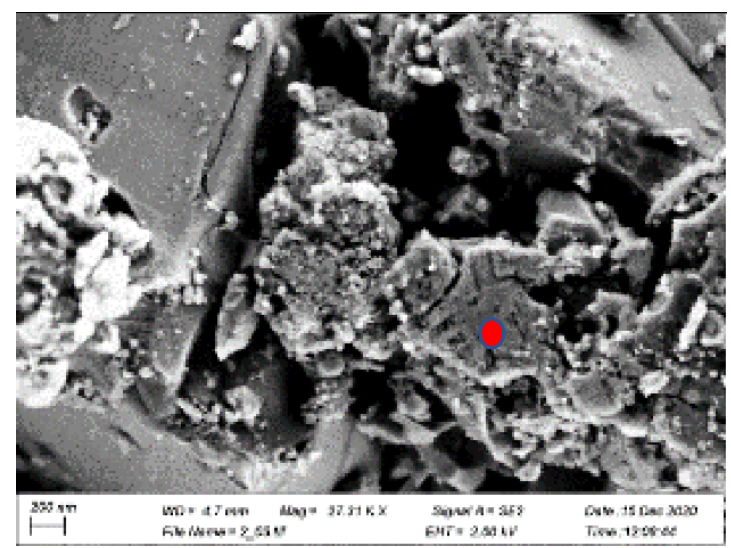

Figure 12 Detail of the cementing hydrates in figure 11 . The elemental composition of the cement (marked with a red dot) is shown in figure 13.

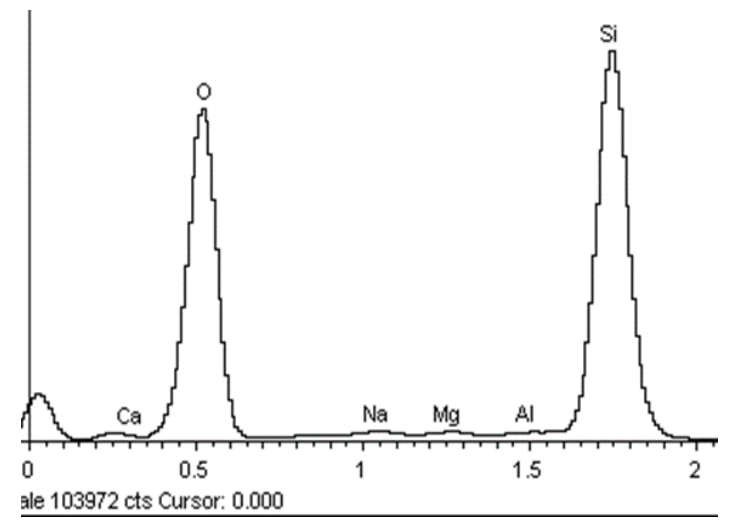

Figure 13 Elemental composition of the silica cement in figure 12. 


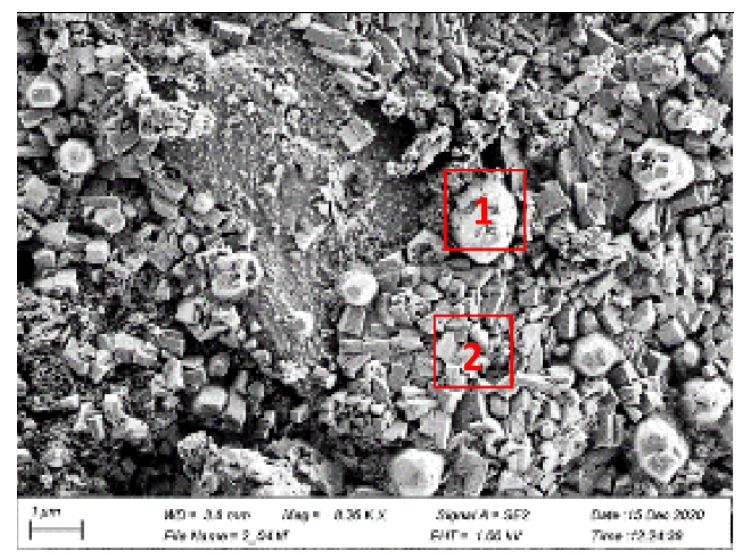

Figure 14 Microstructure of the $\mathrm{Na}_{2} \mathrm{SiO}_{3}+\mathrm{NaOH}$ activated GGBS cured at $60^{\circ} \mathrm{C}$ after 270 days, with abundant octahedral and tabular silicates (Figures 15-16).

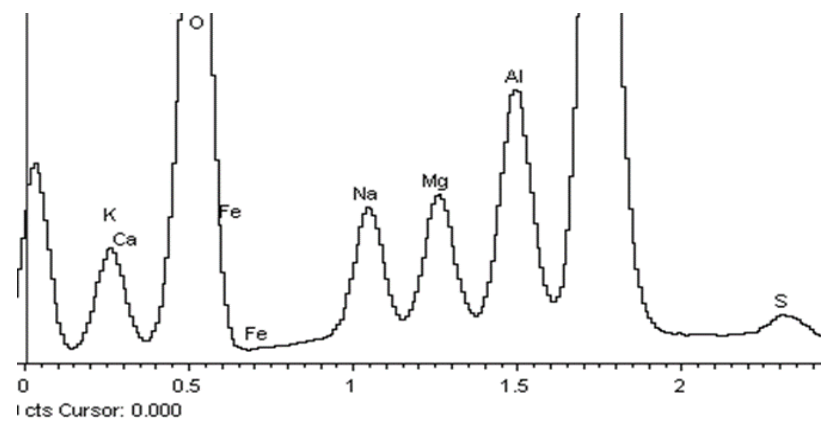

Figure 15 Elemental composition of the octahedral silicates. Spectrum 1 of figure 14.

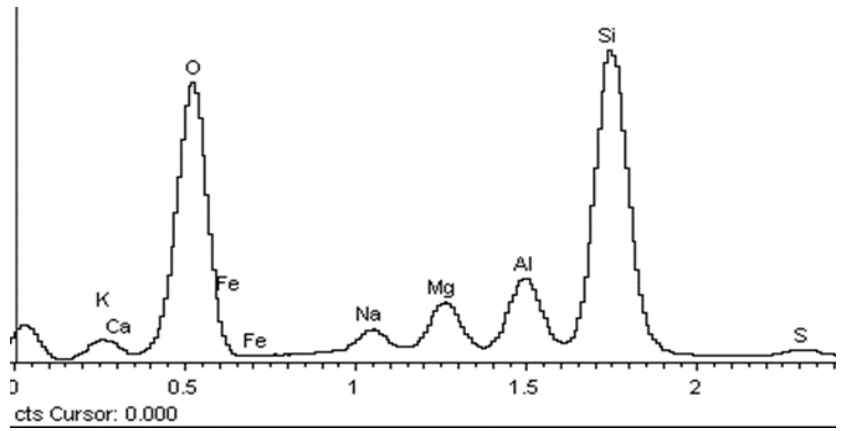

Figure 16 Elemental composition of the tabular silicates. Spectrum 2 of figure 14.

This microstructure agrees with previous authors. It is well known that the main reaction product in alkali silicate activated slag binders is a poorly crystalline C-A-S-H type gel. However, hydrogarnets such as katoite have also been found [62]. The elemental composition of the abundant octahedral and tabular phases evidenced suggests that they are calcium alumino silicates (figures 15-16), some including $\mathrm{Mg}$. The $\mathrm{Na}$ content is provided by the activator and picked up by the scattered EDX beam. The presence of these phases is in agreement with the alumina content of the GGBS (approximately $12 \%)$. The octahedral crystals are likely the garnet katoite, a member of the $\mathrm{Ca}_{3} \mathrm{Al}_{2}\left(\mathrm{SiO}_{4}\right)_{3^{-}}$ $\mathrm{Ca}_{3} \mathrm{Al}_{2}\left(\mathrm{SiO}_{4}\right)_{3}(\mathrm{OH})_{12}$, calcium aluminum silicate hydrate series of the hydrogrossular group. It is similar to the mineral identified by Passaglia and Rinaldi [63] in natural outcrops associated to lava flows. The appearance of this phase has been facilitated by the curing at $60^{\circ} \mathrm{C}$ [64]. 


\section{Conclusion}

It is clear from the study that the $\mathrm{Na}_{2} \mathrm{SiO}_{3}+\mathrm{NaOH}$ activated GGBS specimens have the greatest resilience to the effects of frost, thermal and moisture cycles and salt action, as they remained intact after cycling and showed the greatest strenghts. Their microstructure seems unaltered after cycling, consisting of areas of unreacted GGBS particles and scattered silica cements alternating with alumino-silicates. In contrast, both the $\mathrm{NaOH}$ and the $\mathrm{Na}_{2} \mathrm{SiO}_{3}$ activated $\mathrm{GGBS}$ materials developped slight decay forms as a result of cycling, including salt efflorescence and microcracks. The occurrence of salt efflorescence is relatively common in both the $\mathrm{Na}_{2} \mathrm{SiO}_{3}$ and the $\mathrm{NaOH}$ activated specimens following cycling, and it is likely due to the releasing of sodium cations form the matrix and the superficial precipitation of the salt solution. The high Ca content of this slag has probably reduced drying-shrinkage cracking and contributed to the sound microstructure of the materials.

In most instances, the mechanical strength improves over time in the slag materials investigated, significantly increasing between 28 and 270 days. Despite the exaggerated weathering conditions of the laboratory cycling, the strength loss and micro/macro damage after cycling is minimum except for a few of the $\mathrm{Na}_{2} \mathrm{SiO}_{3}$ activated slag materials.

Raising the curing temperature enhances the strengths of the $\mathrm{Na}_{2} \mathrm{SiO}_{3}+\mathrm{NaOH}$ activated slag materials at all ages, however the increase is small except for the 28-day compressive strength that grows by $23 \%$. At early ages (up to 28 days) increasing curing temperature also enhances the flexural strengths of the $\mathrm{NaOH}$ and $\mathrm{Na}_{2} \mathrm{SiO}_{3}$ activated slags but lowers their compressive strengths. The general tendency is that increasing curing temperature does not significantly enhance the late mechanical strength ( 270 days): it slightly improves the strengths of the $\mathrm{Na}_{2} \mathrm{SiO}_{3} / \mathrm{NaOH}$ and $\mathrm{NaOH}$ activated mixes but lowers the strengths of the $\mathrm{Na}_{2} \mathrm{SiO}_{3}$ activated specimens.

\section{Acknowledgements}

The authors thank the Saudi Arabian Cultural Bureau, the Embassy of Saudi Arabia and the SA Technical \& Vocational Training Corporation for their support, and for financing this project. We thank our colleagues in the Engineering laboratories for their help with the physical testing: M. Gilligan and E. Dunne, and in particular, M. Grimes, Chief Technician D. McAuley and P. Veale. Also, J. Reddy of Ecocem, R. Goodhue and T. Dornan of TCD Geochemistry; A. Rafferty, of the Centre for Adaptive Nanostructures and Nanodevices, TCD; O. Clarkin, Dublin City University, and J. Canavan, Geography Department, TCD, for their assistance with analyses.

\section{Author Contributions}

Omar Alelweet, PhD candidate, completed all the laboratory work, processed the results and studied the background. Sara Pavia, PhD supervisor, wrote the paper.

\section{Competing Interests}

The authors have declared that no competing interests exist.

\section{References}

1. Andrew RM. Global $\mathrm{CO}_{2}$ emissions from cement production. Earth Syst Sci Data Discuss. 2017: 1-52. doi: 10.5194/essd-2017-77. 
2. Luo R, Cai Y, Wang C, Huang X. Study of chloride binding and diffusion in GGBS concrete. Cem Concr Res. 2003; 33: 1-7.

3. Li J, Yao Y. A study on creep and drying shrinkage of high performance concrete. Cem Concr Res. 2001; 31: 1203-1206.

4. Higgins D. Increased sulfate resistance of ggbs concrete in the presence of carbonate. Cem Concr Compos. 2003; 25: 913-919.

5. Binici H, Aksoğan O. Sulfate resistance of plain and blended cement. Cem Concr Compos. 2006; 28: 39-46.

6. Barnett S, Soutsos M, Millard S, Bungey J. Strength development of mortars containing ground granulated blast-furnace slag: Effect of curing temperature and determination of apparent activation energies. Cem Concr Res. 2006; 36: 434-440.

7. Wainwright $P$, Rey $N$. The influence of ground granulated blastfurnace slag (GGBS) additions and time delay on the bleeding of concrete. Cem Concr Compos. 2000; 22: 253-257.

8. Pavía S, Condren E. Study of the durability of OPC versus GGBS concrete on exposure to silage effluent. J Mater Civ Eng. 2008; 20: 313-320.

9. Fernández-Jiménez A, Palomo J, Puertas F. Alkali-activated slag mortars: Mechanical strength behaviour. Cem Concr Res. 1999; 29: 1313-1321.

10. Bakharev T, Sanjayan JG, Cheng YB. Effect of elevated temperature curing on properties of alkali-activated slag concrete. Cem Concr Res. 1999; 29: 1619-1625.

11. Roy DM. Alkali-activated cements opportunities and challenges. Cem Concr Res. 1999; 29: 249254.

12. Brough AR, Atkinson A. Sodium silicate-based, alkali-activated slag mortars: Part I. Strength, hydration and microstructure. Cem Concr Res. 2002; 32: 865-879.

13. Law DW, Adam AA, Molyneaux TK, Patnaikuni I. Durability assessment of alkali activated slag (AAS) concrete. Mater Struct. 2012; 45: 1425-1437.

14. Wardhono A, Law DW, Molyneaux TC. Strength of alkali activated slag and fly ash-based geopolymer mortar. Proceedings of the Second International Conference on Microstructuralrelated Durability of Cementitious Composites; 2012 April 11-13; Amsterdam, The Netherlands.

15. Shi C, Roy D, Krivenko P. Alkali-activated cements and concretes. Boca Raton, Florida: CRC Press; 2006.

16. Collins F, Sanjayan J. Early age strength and workability of slag pastes activated by sodium silicates. Mag Concr Res. 2001; 53: 321-326.

17. Collins F, Sanjayan J. Microcracking and strength development of alkali activated slag concrete. Cem Concr Compos. 2001; 23: 345-352.

18. Puertas F, Gutierrez R, Fernández-Jiménez A, Delvasto S, Maldonado J. Alkaline cement mortars. Chemical resistance to sulfate and seawater attack. Mater de Construccion. 2002; 52: 55-71.

19. Altan E, Erdoğan ST. Alkali activation of a slag at ambient and elevated temperatures. Cem Concr Compos. 2012; 34: 131-139.

20. Bakharev T, Sanjayan JG, Cheng YB. Sulfate attack on alkali-activated slag concrete. Cem Concr Res. 2002; 32: 211-216.

21. San Nicolas R, Bernal SA, de Gutiérrez RM, van Deventer JS, Provis JL. Distinctive microstructural features of aged sodium silicate-activated slag concretes. Cem Concr Res. 2014; 65: 41-51.

22. Qureshi MN, Ghosh S. Alkali-activated blast furnace slag as a green construction material. J Mech Civil Eng. 2014; 2: 24-28. 
23. Alelweet O, Pavia S. Fitness of a high-calcium slag for the production of alkali activated materials. Proceedings of the 1st International Conference on Construction, Energy, Environment and Sustainability - CEES 2021; 2021 October 12-15; Coimbra, Portugal.

24. Hewlett P. Lea's Chemistry of Cement and Concrete. 4th ed. Oxford: Butterworth-Heinemann; 1988.

25. Provis JL, Van Deventer JS. Alkali activated materials: State-of-the-art report, RILEM TC 224AAM. Dordrecht: Springer; 2013

26. Rodríguez E, Bernal S, De Gutiérrez RM, Puertas F. Alternative concrete based on alkaliactivated slag. Mater de Construccion. 2008; 58: 53-67.

27. Provis JL, Muntingh Y, Lloyd RR, Xu H, Keyte LM, Lorenzen L, et al. Will geopolymers stand the test of time? Ceram Eng Sci Proc. 2007; 28: 235-248.

28. Shi C, Xie P. Interface between cement paste and quartz sand in alkali-activated slag mortars. Cem Concr Res. 1998; 28: 887-896.

29. Luga E. Properties of fly ash and blast furnace slag geopolymer mortars. Kayseri, Turkiye: Erciyes University; 2015.

30. Djobo JN, Elimbi A, Tchakouté HK, Kumar S. Mechanical properties and durability of volcanic ash based geopolymer mortars. Constr Build Mater. 2016; 124: 606-614.

31. Fu Y, Cai L, Wu Y. Freeze-thaw cycle test and damage mechanics models of alkali-activated slag concrete. Constr Build Mater. 2011; 25: 3144-3148.

32. Provis JL, van Deventer JS. Alkali activated materials. Dordrecht: Springer; 2014.

33. Kukko H, Mannonen R. Chemical and mechanical properties of alkali-activated blast furnace slag (F-concrete). Nord Concr Res. 1982.

34. Ellis K, Alharbi N, Matheu P, Varela B, Hailstone R. Durability of alkali activated blast furnace slag. IOP Conf Ser Mater Sci Eng. 2015; 96: 012004.

35. Azarsa P, Gupta R. Freeze-thaw performance characterization and leachability of potassiumbased geopolymer concrete. J Compos Sci. 2020; 4: 45.

36. EN15167-1: 2006. Ground granulated blast furnace slag for use in concrete, mortar and grout. Definitions, specifications and conformity criteria [Internet]. Brussels: European Committee for Standardization; $2006 . \quad$ Available from: https://standards.iteh.ai/catalog/standards/cen/ff51b993-7c12-42cf-a561-ddafacccc108/en15167-1-2006.

37. Krivenko $P$, Kavalerova E. Performance of alkali-activated cements-perspective ways for carbon dioxide emissions reduction. Proceedings of the 3rd International Symposium Non-Traditional Cement \& Concrete; 2008 June 10-12; Brno, Czech Republic.

38. Pacheco-Torgal F, Labrincha J, Leonelli C, Palomo A, Chindaprasit P. Handbook of alkaliactivated cements, mortars and concretes. Cambridge, US: Woodhead Publishing; 2014.

39. Bakharev T, Sanjayan JG, Cheng YB. Effect of admixtures on properties of alkali-activated slag concrete. Cem Concr Res. 2000; 30: 1367-1374.

40. Hardjito D, Rangan BV. Development and properties of low-calcium fly ash-based geopolymer concrete. Perth, Australia: Curtin University of Technology; 2005.

41. Wallah SE, Rangan BV. Low-calcium fly ash-based geopolymer concrete: Long-term properties. Perth: Curtin University of Technology; 2006; GC 2.

42. Parthiban K, Saravanarajamohan K, Shobana S, Bhaskar AA. Effect of replacement of slag on the mechanical properties of fly ash based geopolymer concrete. Int J Eng Technol. 2013; 5: 25552559. 
43. Das SK, Banerjee S, Jena D. A review on geo-polymer concrete. Int J Eng Res Technol. 2013; 2: 2785-2788.

44. EN 1015-3: 1999. Methods of testing mortar for masonry [Internet]. Brussels: European Committee for Standardization; $1999 . \quad$ Available from: https://standards.iteh.ai/catalog/standards/cen/f427f20a-2746-4ab7-bd55d1c455b1f009/en-1015-3-1999.

45. RILEM. Recommended tests to measure the deterioration of stone and to assess the effectiveness of treatment methods. Mater Constr. 1980; 13: 175-253.

46. EN15304: 2010. Determination of the freeze-thaw resistance of autoclaved aerated concrete [Internet]. Brussels: European Committee for Standardization; 2010. Available from: https://standards.iteh.ai/catalog/standards/cen/412c9869-4350-403a-83d847cbc0d80305/en-15304-2010.

47. EN1015-11: 1999. Methods of test for mortar for masonry. Determination of flexural and compressive strength of hardened mortar [Internet]. Brussels: European Committee for Standardization; $1999 . \quad$ Available from: https://standards.iteh.ai/catalog/standards/cen/7a575e90-4735-4c98-80349ec96633f0d2/en-1015-11-1999.

48. Alelweet $\mathrm{O}$, Pavia S. Potential of a low-calcium fly ash (FA) for the production of alkali-activated materials. Proceedings of the Civil Engineering Research in Ireland; 2020 August 27-28; Cork, Ireland.

49. BS 8500-1: 2015+A2: 2019. Concrete. Complementary BS to EN 206. Method of specifying and guidance for the specifier. Brussels: European Committee for Standardization; 2019. Available from: https://www.en-standard.eu/bs-8500-1-2015-a2-2019-concrete-complementarybritish-standard-to-bs-en-206-method-of-specifying-and-guidance-for-the-specifier/.

50. Wang SD, Scrivener KL, Pratt P. Factors affecting the strength of alkali-activated slag. Cem Concr Res. 1994; 24: 1033-1043.

51. Ke X, Bernal SA, Ye N, Provis JL, Yang J. One-part geopolymers based on thermally treated red mud/NaOH blends. J Am Ceram Soc. 2015; 98: 5-11.

52. Allahverdi A, Mehrpour K, Kani EN. Investigating the possibility of utilizing pumice-type natural pozzonal in production of geopolymer cement. Ceram Silik. 2008; 52: 16-23.

53. Kani EN, Allahverdi A. Effect of chemical composition on basic engineering properties of inorganic polymeric binder based on natural pozzolan. Ceram Silik. 2009; 53: 195-204.

54. Kani EN, Allahverdi A, Provis JL. Efflorescence control in geopolymer binders based on natural pozzolan. Cem Concr Compos. 2012; 34: 25-33.

55. Pacheco-Torgal F, Jalali S. Influence of sodium carbonate addition on the thermal reactivity of tungsten mine waste mud based binders. Constr Build Mater. 2010; 24: 56-60.

56. Škvára F, Kopecký L, Myšková L, Šmilauer V, Alberovska L, Vinšová L. Aluminosilicate polymersinfluence of elevated temperatures, efflorescence. Ceram Silik. 2009; 53: 276-282.

57. Temuujin J, Van Riessen A. Effect of fly ash preliminary calcination on the properties of geopolymer. J Hazard Mater. 2009; 164: 634-639.

58. Lloyd RR, Provis JL, Van Deventer JS. Pore solution composition and alkali diffusion in inorganic polymer cement. Cem Concr Res. 2010; 40: 1386-1392.

59. Bortnovsky O, Dědeček J, Tvarůžková Z, Sobalík Z, Šubrt J. Metal ions as probes for characterization of geopolymer materials. J Am Ceram Soc. 2008; 91: 3052-3057.

60. Szklorzová H, Bílek V. Influence of alkali ions in the activator on the performance of alkali- 
activated mortars. Proceedings of the 3rd International Symposium Non-Traditional Cement \& Concrete; 2008 June 10-12; Brno, Czech Republic.

61. Zhang Z, Provis JL, Reid A, Wang H. Fly ash-based geopolymers: The relationship between composition, pore structure and efflorescence. Cem Concr Res. 2014; 64: 30-41.

62. Bernal SA, Provis JL, Walkley B, San Nicolas R, Gehman JD, Brice DG, et al. Gel nanostructure in alkali-activated binders based on slag and fly ash, and effects of accelerated carbonation. Cem Concr Res. 2013; 53: 127-144.

63. Passaglia $\mathrm{E}$, Rinaldi R. Katoite, a new member of the $\mathrm{Ca}_{3} \mathrm{Al}_{2}\left(\mathrm{SiO}_{4}\right)_{3}-\mathrm{Ca}{ }_{3} \mathrm{Al}_{2}(\mathrm{OH})_{12}$ series and a new nomenclature for the hydrogrossular group of minerals. Bull de Minéral. 1984; 107: 605-618.

64. Kyritsis K, Meller N, Hall C. Chemistry and morphology of hydrogarnets formed in cement-based CASH hydroceramics cured at $200^{\circ}$ to $350^{\circ}$ C. J Am Ceram Soc. 2009; 92: 1105-1111.

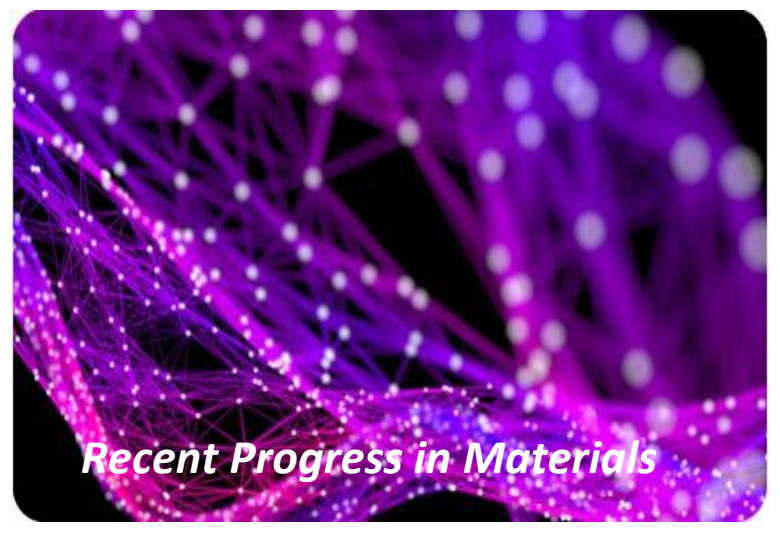

Enjoy Recent Progress in Materials by:

1. Submitting a manuscript

2. Joining in volunteer reviewer bank

3. Joining Editorial Board

4. Guest editing a special issue

For more details, please visit:

http://www.lidsen.com/journals/rpm 